\title{
Proposing a Typology of Ludification as a Translation Technique for PC, Console, Mobile and Online Games
}

\section{SF. Luthfie Arguby Purnomo ${ }^{*}$, SF. Lukfianka Sanjaya Purnama ${ }^{2}$, Lilik Untari ${ }^{3}$, Arynaa Azahra ${ }^{4}$, Nadya Octaviana Pramana Putri ${ }^{5}$}

\author{
${ }^{1}$ Sastra Inggris, UIN Raden Mas Said Surakarta, Indonesia. E-mail: theluthfie@gmail.com \\ ${ }^{2}$ Sastra Inggris, UIN Raden Mas Said Surakarta, Indonesia. E-mail: $\overline{\text { iaftersmile@gmail.com }}$ \\ ${ }^{3}$ Sastra Inggris, UIN Raden Mas Said Surakarta, Indonesia. E-mail: nazala.suha@gmail.com \\ ${ }^{4}$ Sastra Inggris, UIN Raden Mas Said Surakarta, Indonesia. E-mail: arynaa.azzahra@gmail.com \\ ${ }^{5}$ Sastra Inggris, UIN Raden Mas Said Surakarta, Indonesia. E-mail: nadyaoctaviana01@gmail.com \\ *Corresponding author
}

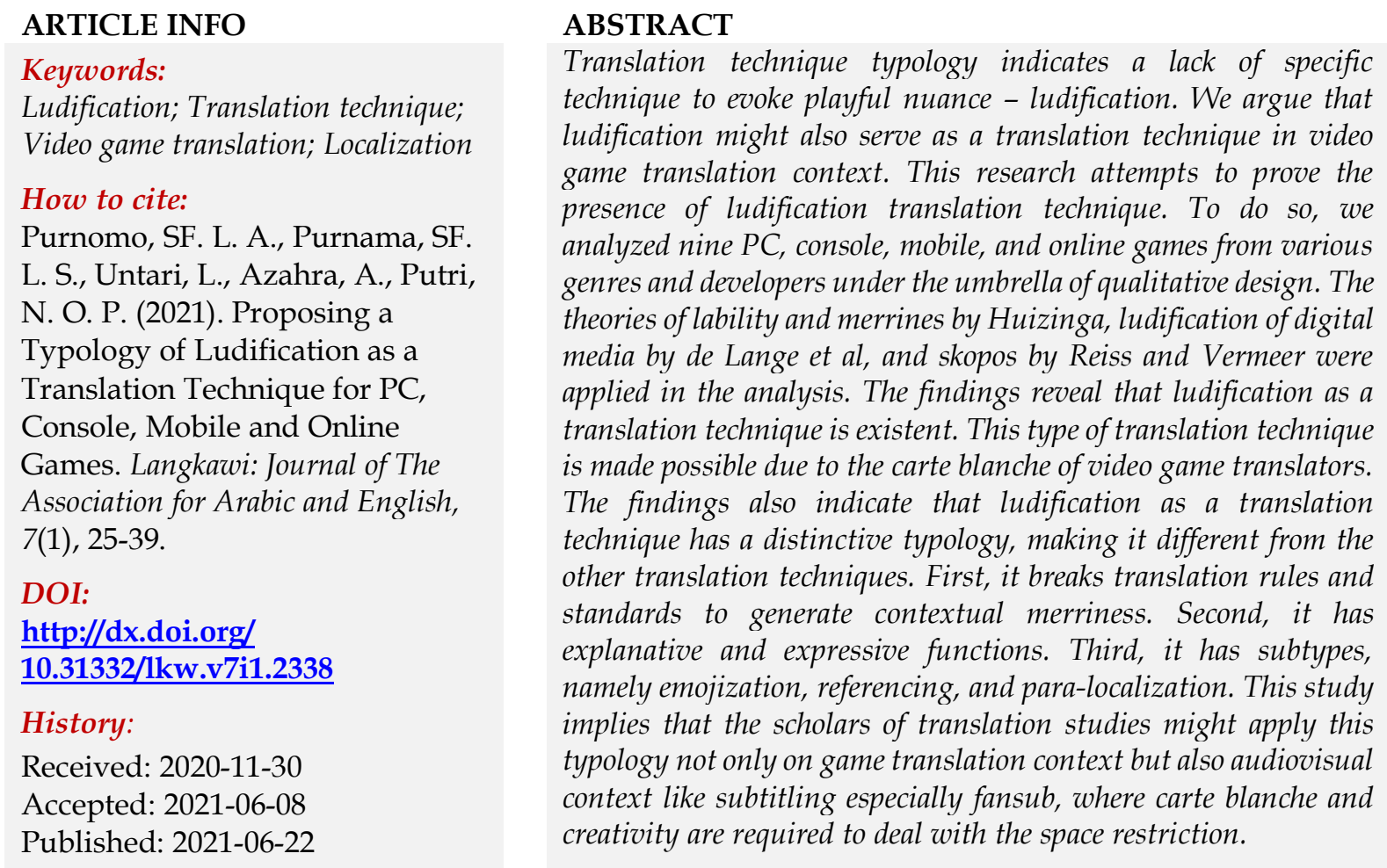

\section{Introduction}

Transferring messages 'accurately' almost always begets problems and those problems need to be dealt with solutions. Scholars of translation studies like Krings (1986) calls them translation strategies while Molina \& Hurtado Albir (2002) call them techniques. Whatever the terms they call and apply, the functions are the same: to deal with accuracy problems. Here we take the latter as our guide to write this piece. What makes them different, as implied by Gambier (2010), is their implementation. Strategies are process-related, while techniques are product-related.

Translation techniques as formulated by Molina and Albir leave the facts that translators have skopos, which claims that the purposes of translating a text determine the translation process (Reiss \& Vermeer, 2014). One of the purposes is playfulness or a ludification. Ludification emphasizes on the adoption and utilization of play and 
game's philosophical backgrounds, concepts, frameworks, mechanism, and procedures in any domains of cultural and social area without no exemption (Korhonen et al., 2009; Frissen, 2015). To ludify an object indicates that the ludifier and those the ludification is directed to are homo ludens, a playful creature (Huizinga, 2014). To ludify an object also points out that the ludifier applies what Huizinga (2014) calls lability and merrines. The former refers to breaking rules and standards, while the latter refers to the playful effect of breaking rules and standards. Therefore, we can say that ludification in translation context deals with breaking the rules and standards of translation to generate a playful effect while at the same time maintaining the accuracy of the transferred messages. The following example from the translation of Sui Arts' Dentures and Demons from English to Indonesian might illustrate what ludification in translation context is:

ST (Source Text):
TT (Target Text):
BT (Back Translation):
GOT writers did a magnificent work with season 8 ! OVJ yang sekarang nggak lucu kayak yang dulu!

OVJ (Opera Van Java - a famous television comedy program) is no longer funny like it used to be!

The game's translator localizes Games of Throne into Opera Van Java in a playful or parodic nuance. This nuance is perceptible from how the translator breaks the rules of accuracy by localizing GOT into OVJ. Though the translator breaks the translation rules, the decision to localize GOT into OVJ is acceptable. The localization is acceptable since it fits with the sarcastic comedy of the game.

This ludic phenomenon in the context of translation studies, as indicated by Purnomo et al. (2021), Guyker Jr. (2016), Purnomo et al. (2016), and Schules (2012), is more perceptible from translation exercised by fans or what is called as fan translation. This translation type which is also known as user generated translation (Ding et al., 2021) covers a wide range of translation type from comics scanlation (Inose, 2012), fansubbing (Massidda, 2015), fandub (Baños, 2020), and rom hacking or fan localization (Consalvo, 2013). These creative activities are marked by one primary distinctive feature - rule-breaking. This rule-breaking encompasses intrinsic and extrinsic elements of the translated texts. Intrinsic elements cover any textual elements of the translated texts like typography, screen position, voice bubbles, and the other elements. On the other hand, extrinsic elements cover the legal status, distribution, dissemination, and publicity of the translated texts. This wide array of rule-breaking activities indicates the presence of playfulness by the fan translators. This condition further implies that ludification is existent in any translation process - a gap left by the previous studies to which this study attempts to fill.

Departing from this phenomenon of ludification in translation context, we attempt to study it through the lens of translation techniques. These lens we use are the vital point of translation process since translation techniques hold a significant role in delivering messages and solving translation problems. We argue that ludification is a gap left behind in translation technique context. We hold a view that ludification should be adopted as a translation technique since it corresponds to a specific problem and possesses a specific feature. Departing from this gap left by previous translation technique formulation, we propose the following research question to answer: What typology of ludification translation technique can be constructed? 


\section{SF. Luthfie Arguby Purnomo, SF. Lukfianka Sanjaya Purnama, Lilik Untari, Arynaa}

Azahra, Nadya Octaviana Pramana Putri: Proposing a Typology of Ludification as a Translation Technique for PC, Console, Mobile and Online Games

The constructed typology will encompass the characteristics, functions, and sub types of ludification translation technique. Through these characteristic, function, and sub type identification, translation scholars might recognize the distinctive features, functions, and sub types of ludification translation technique.

Translation techniques hold a significant role for both translators and the scholars of translation studies. Chaume (2004) indicates that translation techniques to solve particular translation problems are an automatic response from within the translator's minds. Since translation techniques are implemented as a translation problem solver, it implies that the scholars of translation studies could reveal both the problems and the solutions for the problems through translation technique analysis.

Translators and translation scholars often face two major issues of translation techniques. Those issues are cultural issues as implied by Fawcett (2003) and terminology issues as implied by Nord (2003). In dealing with these issues, as stated by Đorđević (2017), the scholars of translation studies have proposed various solutions since Vinay and Dalbenet in the late 1950s to Molina and Albir in the early 2000s. It indicates that translation techniques keep on being revisited since new translation problems arise and the birth of new media, new perspectives, and new audiences.

New media generates significant impacts on translation in terms of problems. One of the problems is the negotiation between message accuracy and technical or mechanical restriction of the media. Film subtitling, dubbing, and video game localization are examples of how translators are forced to negotiate between accuracy and spatial restrictions. Thus, translation techniques that are constructed to address linguistic issues and nonlinguistic issues are required to deal with these restriction problems. New perspectives or paradigms on how messages are delivered also trigger new translation problems. Skopos, for example, where translation is carried out based on purposes (Reiss \& Vermeer, 2014), influences how message accuracy and acceptability are questioned and revisited. In fansubs, for instance, since the skopos of this translation mode is to serve the fans, fansubbers could do anything on the screen to make the messages accurate and acceptable by the fans' standards. In the context of fansub, these fans are also an example of new audiences to which translators need to address. The subtitles appearing on the screen objects that say particular messages in nonfansub movies point out that fans with their distinctive subtitles are valued and addressed.

The act of translating a text shares ludic concepts as that of the act of playing a game. Cronin (1995a, 2007b) addresses this issue by articulating five ludic concepts found in translation: simulation, metaphor, paradox, distance, and limit. Homo ludens perspectives by Huizinga (2014) highlights these five ludic concepts on the fundamental philosopical background of lability and merriness, from which ludification emerges. This practice of lability or rule breaking for merriness occurs primarily on fan translation with fansub being the most widely ludified fan translation. Schules (2012) sees fansubs especially anime or Japanese animation fansubs as a ludic practice. He further claims that fansubbers do a ludic negotiation between texts and fans with rule and structure adjustment in anime fansubs as the tool of 
negotiation. This ludic negotiation compels fansubbers to break subtitling rules or standards to meet what fans want.

The rule breaking performed by fans for fans points out that translation in ludification context circumnavigates around transferring textual messages and nontextual ones - the visual and operational messages. This context of translation tends to emphasize functional elements more than structural elements. In functional translation, translation techniques are applied for different functions (Nord, 2018). Ludification or playfulness is one of functions to which translation techniques need to address since it defines the functionality of fan translation. This ludic function appears not only on fan or user generated translation but also translation which addresses products identical or laden with playfulness like parody and children translation. Translators are sometimes forced to move beyond structural domain to translate the works through merriness gained lability functionally to address these playful works. To deliver the same ludic engagement as the source text, staying faithful to the source text is sometimes an option not taken. Breaking the rules or standards is often exercised to ensure that the source and target audiences laugh over the same text though the text has been translated.

\section{Method}

\subsection{Design and Procedure}

We conducted this qualitative study in three steps. First, we collected nine English, Japanese, and Indonesian games along with their translations. The translatiosn, either being translated by fans or professionals, had to indicate ludification in the forms of rule or standard breaking for merriness. Second, we collected the data in the forms of words, phrases, clauses, and sentences that indicated ludification implementation. Third, we applied domain, taxonomy, componential, and finding cultural theme analysis by Spradley (2016). In domain analysis, we differentiated between data and nondata by applying lability and merrines theory by Huizinga (2014), ludification of digital media culture by Frissen (2015), and skopos by Reiss \& Vermeer (2014). Words, phrases, clauses, and sentences which were categorized into data were those which showed rule breaking for merriness concept. After the data were collected in taxonomy analysis, the data were classified based on their types and functions in a typological fashion. After classifying the data typologically, the relationship between the types, the functions, and the media was analyzed to reveal how particular ludification types and functions generated impacts on the translation results. In the last step of analysis, the result of the relationship analysis was related and signified with the status of being fan or professional translation.

\subsection{Data and Sources of Data}

This research data are lingual expressions that indicate that they have been ludified in the translation process. The data were taken from the sources as shown by table 1.

We selected the titles as seen from table 1 since they displayed the ludification of lingual expressions in the target texts. This ludification was seen from the rulebreaking done by the translators. The rule-breaking encompasses the breaking of mechanical and narrative elements of the game to evoke particular nuance of 
merriness. This study's merriness is not merriness due to technical or lingual errors but contextual merriness to avoid any bias. This contextual merriness is merriness in which the translation is considered to be out of the context. The researchers collected the data by playing the games, screen shooting the parts that indicate ludification, and compiling and sorting them based on their similar characteristics. Lability and merrines theory by Huizinga (2014) is applied to ensure that each datum indicates the existence of ludification.

Table 1. Data Sources

\begin{tabular}{|c|c|c|c|c|c|}
\hline Source Titles & Target Titles & Genres & $\begin{array}{c}\text { Developers/ } \\
\text { Publishers }\end{array}$ & Languages & Platforms \\
\hline Buff Knight & Jagoan Jones & $\begin{array}{l}\text { Endless } \\
\text { Runner }\end{array}$ & Buff Studio & $\begin{array}{l}\text { English to } \\
\text { Indonesian }\end{array}$ & Mobile \\
\hline Bumbu Cinta & Love Spice & $\begin{array}{l}\text { Visual } \\
\text { Novel }\end{array}$ & Agate Studio & $\begin{array}{l}\text { Indonesian to } \\
\text { English }\end{array}$ & Mobile \\
\hline $\begin{array}{l}\text { Darkness } \\
\text { Rises }\end{array}$ & Darkness Rises & $\begin{array}{c}\text { Adventure } \\
\text { RPG }\end{array}$ & Nexon & $\begin{array}{l}\text { English to } \\
\text { Indonesian }\end{array}$ & Mobile \\
\hline $\begin{array}{l}\text { Dentures and } \\
\text { Demons }\end{array}$ & $\begin{array}{l}\text { Dentures and } \\
\text { Demons }\end{array}$ & Adventure & Sui Arts & $\begin{array}{l}\text { English to } \\
\text { Indonesian }\end{array}$ & Mobile \\
\hline $\begin{array}{c}\text { Final Fantasy } \\
\text { XIII }\end{array}$ & $\begin{array}{c}\text { Final Fantasy } \\
\text { XIII }\end{array}$ & RPG & Square Enix & $\begin{array}{l}\text { Japanese to } \\
\text { English }\end{array}$ & Console \\
\hline $\begin{array}{c}\text { Grand Theft } \\
\text { Auto: San } \\
\text { Andreas }\end{array}$ & $\begin{array}{l}\text { Grand Theft } \\
\text { Auto: San } \\
\text { Andreas }\end{array}$ & $\begin{array}{l}\text { Open } \\
\text { World }\end{array}$ & $\begin{array}{l}\text { Rockstar } \\
\text { Games }\end{array}$ & $\begin{array}{l}\text { English to } \\
\text { Indonesian }\end{array}$ & PC/Console \\
\hline $\begin{array}{c}\text { Harvest Moon } \\
\text { Back to } \\
\text { Nature }\end{array}$ & $\begin{array}{l}\text { Harvest Moon } \\
\text { Back to Nature }\end{array}$ & Farm Sim & Natsume & $\begin{array}{l}\text { English to } \\
\text { Indonesian }\end{array}$ & PC/Console \\
\hline Rockman X5 & Megaman X5 & Platformer & Capcom & $\begin{array}{l}\text { Japanese to } \\
\text { English }\end{array}$ & Console \\
\hline $\begin{array}{l}\text { Spider Man: } \\
\text { Unlimited }\end{array}$ & $\begin{array}{l}\text { Spider Man: } \\
\text { Unlimited }\end{array}$ & $\begin{array}{l}\text { Endless } \\
\text { Runner }\end{array}$ & Gameloft & $\begin{array}{l}\text { English to } \\
\text { Indonesian }\end{array}$ & Mobile \\
\hline
\end{tabular}

3. Findings and Discussion

We divide this section into two parts namely findings and discussion. In the finding section, we present the typology of ludification technique. The typology comprises the characteristics, the functions, and the sub types of ludification technique. After presenting the typology, we discuss the findings. We focus the discussion on the problems of ludicity level in ludification translation technique context.

\subsection{The Typology of Ludification Translation Technique}

We found that there were three subtypes of ludification translation technique namely emojization, referencing, and para-localization. Emojization deals with adding emoji on the target texts. Referencing deals with referring to the target culture related particular objects. Para-localization deals with localizing an object or an expression of which the target object or expression is nonexistent. The table 2 contains detailed number of these types from each game that we analyzed. 
That referencing is the most dominant sub technique of ludification points out that the ludic aspects of the localization was negotiated - not too glaring in expression while pertaining the explanative side of the localization and the degree of accuracy of the localized messages. On the other hand, emojization and para-localization tend to only lean over the expressive side of the localization while ignoring the degree of accuracy on the explanative side.

Table 2. Findings on Emojization, Referencing, and Para-Localization

\begin{tabular}{lccc}
\hline & Emojization & Referencing & Para-Localization \\
\hline Buff Knight & 2 & 3 & $\mathrm{x}$ \\
Bumbu Cinta & $\mathrm{x}$ & 2 & $\mathrm{x}$ \\
Darkness Rises & $\mathrm{x}$ & $\mathrm{x}$ & 1 \\
Dentures and Demons & $\mathrm{x}$ & 42 & $\mathrm{x}$ \\
Final Fantasy XIII & $\mathrm{x}$ & 50 & 1 \\
Grand Theft Auto: San Andreas & $\mathrm{x}$ & 24 & $\mathrm{x}$ \\
Harvest Moon Back to Nature & $\mathrm{x}$ & 4 & $\mathrm{x}$ \\
Rockman X5 & $\mathrm{x}$ & 8 & $\mathrm{x}$ \\
Spider Man: Unlimited & $\mathrm{x}$ & 2 & $\mathrm{x}$ \\
\hline
\end{tabular}

These subtypes of ludification are made possible through the rule-breaking of video games' narrative and mechanical aspects. This rule-breaking is intended to evoke contextual merriness, which is the distinctive characteristic of ludification.

Table 3. Ludification Translation Technique Typology

\begin{tabular}{ccc}
\hline Characteristics & Functions & Types \\
Rule-Breaking & Expressive & Emojization \\
Contextual Merriness & Explanative & Referencing \\
& & Para-localization
\end{tabular}

Video game translation, just like the other audiovisual translation branches, has standards which regulate how textual messages should be delivered with the concerns on medial aspects. For example, subtitles in video game translation context, though varied on textual and visual presentation, generally have the same standard as those of films. This mechanical standard, ranging from font type selection to text positioning, is violated to deliver a playful narrative message. Video game translations by fans are often spotted to apply this mechanical and narrative rule-breaking through the implementation of modding. This in-game object modification is made possible through particular computer programs or self-development kits (SDK). GTA San Andreas and Harvest Moon Back to Nature are the examples of how modding is applied to translate these titles into Bahasa Indonesia - a target language which was never officially existent. Though playfulness or ludification occurs mostly in a fan translation context, it also takes place on a professional translation. The following subsection will discuss each subtype of ludification.

\subsubsection{Emojization}




\section{SF. Luthfie Arguby Purnomo, SF. Lukfianka Sanjaya Purnama, Lilik Untari, Arynaa}

Azahra, Nadya Octaviana Pramana Putri: Proposing a Typology of Ludification as a Translation Technique for PC, Console, Mobile and Online Games

Emoji is playful in nature. The use of emoji is widely known in gaming language context. Games like Harvest Moon Back to Nature make use of emojis to flavor the game dialogues. In Harvest Moon Back to Nature, love emojis dominate the game especially after the player controlled protagonist marries a character in the game. In game translation context, game translators use this paralinguistic object in their translation to ludify the text. The implementation of emojization is aimed at substituting verbal expressions, adding extra information unconveyed on the source text, or facilitating the translator's emotion. The following example might help indicate what emojization is:

ST: $\quad$ Please, recommend this game to your friends so we can add more heroes!

TT: $\quad$ Silahkan merekomendasikan ke banyak orang dan akan ada karakter baru yang ditambahkan $>_{-}<$

BT: Please, recommend (this game) to a lot of people and there will be a new character added $>$ _<

The excerpt was taken from Buff Knight, a comedic endless runner game from Buff Studio. To intensify the comedic nuance of the game, the translators employ a literary device which is called 'breaking the fourth wall'. This literary device situates the game characters to talk to the gamers. The translator captures this comedic nuance and strengthens this comedic nuance by breaking the mechanical and textual rules. The mechanical rule-breaking is visible from the enlargement of the target dialogue box to contain rule-breaking texts, as seen from the addition of emoji to replace the exclamatory mark.

In the context of localization, what the translators of Buff Knight do with emojization might be seen to adjust the source text with the target culture. Asking for a help from others, in this case, the gamers, should be politely done and having an exclamatory mark discloses the possibility of being interpreted as impolite. Thus, substituting this mark with a politeness induced paralinguistic object like emoji would serve the purpose of being polite.

The ludification of Buff Knight encompasses the story narratives and the ludification of the game mechanics. An additional menu called lotere (lit. lottery) is presented on the title screen in the Indonesian version. Through this menu, Indonesian gamers are prevented from being bored due to the time consuming gameplay. This menu ludifies the game since it adds merrines in gameplay context. This practice of ludification is commonly found in a fan video game translation. For instance, in GTA San Andreas, modding enables players to do almost anything from shattering to constructing any in-game objects. This kind of ludification offers merriness beyond textual domain. This merriness immerses oneself to the game world through its gameplay.

Emojization is a bridge for the translators to express themselves. Since the source text has indicated that the game employs a fourth wall-breaking device to trigger a comedic nuance, adding emoji tends to be acceptable.

\subsubsection{Referencing}

Referencing refers to object, personage, and expression adaptation or adoption by referring to the objects, personages, and expressions considered representative in the 
target culture. Referencing might disclose possibilities to evoke merriness since what the source text attempts to convey on the source text might be deviated or violated on the target text. This condition further implies that by referencing, translators might break what it denotes by equivalence.

\subsubsection{Object Referencing}

Famous objects are often made as a reference to ludify the source text through a translation process. GOT to OVJ as found from Dentures and Demons is the example of object referencing. Another example is visible from Buff Knight:

ST: No rain today? I want some hot cocoa-

TT: $\quad$ Kenapa hari ini ga hujan sih? Mau makan Ind*mie pakai bakso padahal.

BT: Why isn't it raining today, huh? Wanna grab Ind*mie (famous noodle brand in Indonesia) with meatball.

The translator employs object referencing by referring to a famous Indonesian noodle brand. This reference indicates that the translator fathoms that warm noodles are a culinary product associated with rain in Indonesia. This localization fits with the core message of the source text which emphasizes beverage association with weather. In ludification perspectives, this reference can incite a contextual merriness due to the desynchronization between the said and the sayer, a knight in a medieval armor suit.

\subsubsection{Personage Referencing}

As seen from object referencing, popular culture references have a significant cultural consideration though the nuance generated from the translation is comedic. These references are found also in personages or figures. In personage referencing, this significant cultural consideration is not always the case as the consideration could be personal. The table 4 sd example from Rockman X5, which was translated into Megaman X5, might help comprehend this statement.

As stated on Megaman Knowlege Base (MMKB), the English names of the boss characters, to which the players have to beat, as shown on the table above, refer to Guns n Roses' personnel's names. Alyson Court's translator applied this reference to honor her husband, Erik Suzuki, who was a rock band fan. It is unique because Alyson Court, a professional translator, imbues a fan-like adoring attitude into her translation. This case further implies that professional translators might exercise their translation in a fandom context.

The merriness of the translation emerges when the reference, to some extent, fits symbolically with the visual of the characters. Supaiku Rōzureddo, for example, symbolically fits the rose motif of the band and the last name of the lead vocal, Axl Rose. That Crescent Grizzly is a mechanical bear that attacks by drilling and slashing allusively share the attacks with Slash, the guitarist of Guns $n$ Roses. Michael Monroe, the lead vocalist of Hanoi Rocks, made a guest appearance on Guns $n$ Roses twice and this fact was allusively brought into the name The Skiver - a slang which refers to somebody who skips between classes. These examples of references indicate that ludification might come from personal aims that translators have and it further points out that rule-breaking is existent. That Capcom retranslated the names in the re-release version of the game strengthens this existence of rule-breaking, which might be 
SF. Luthfie Arguby Purnomo, SF. Lukfianka Sanjaya Purnama, Lilik Untari, Arynaa Azahra, Nadya Octaviana Pramana Putri: Proposing a Typology of Ludification as a

Translation Technique for PC, Console, Mobile and Online Games

considered to violate the narrative connectedness between the names, the visuals and the narratives of the characters.

Table 4. Ludified Boss Character Names in Capcom's Megaman X5

\begin{tabular}{|c|c|c|c|c|}
\hline $\begin{array}{c}\text { Japanese } \\
\text { Names }\end{array}$ & $\begin{array}{c}\text { Japanese Names } \\
\text { (romaji) }\end{array}$ & English Names & $\begin{array}{c}\text { Referenced } \\
\text { Names } \\
\text { (Guns } n \\
\text { Roses) }\end{array}$ & $\begin{array}{c}\text { Retranslated } \\
\text { English } \\
\text { Names }\end{array}$ \\
\hline $\begin{array}{c}\text { スパイク・ローズ } \\
\text { レッド }\end{array}$ & Supaiku Rōzureddo & Axle the Red & Axl Rose & Spike Rosered \\
\hline $\begin{array}{c}\text { クレッセント・グ } \\
\text { リズリー }\end{array}$ & Kuressento Gurizurī & Grizzly Slash & Slash & Crescent Grizzly \\
\hline $\begin{array}{c}\text { ボルト・クラーケ } \\
\text { ン }\end{array}$ & Boruto Kurāken & Squid Adler & Steven Adler & Volt Kraken \\
\hline $\begin{array}{c}\text { タイダル・マッコ } \\
\text { イーン }\end{array}$ & Taidaru Makkoīn & Duff McWhalen & $\begin{array}{c}\text { Duff } \\
\text { McKagan }\end{array}$ & Tidal Whale \\
\hline $\begin{array}{c}\text { バーン・ディノレ } \\
\text { ックス }\end{array}$ & Bān Dinorekkusu & Mattrex & Matt Sorum & Burn Dinorex \\
\hline $\begin{array}{c}\text { シャイニング · ホ } \\
\text { タルニクス }\end{array}$ & $\begin{array}{l}\text { Shainingu } \\
\text { Hotarunikusu }\end{array}$ & Izzy Glow & Izzy Stradlin & Shining Firefly \\
\hline $\begin{array}{c}\text { スパイラル・ペガ } \\
\text { シオン }\end{array}$ & $\begin{array}{l}\text { Supairaru } \\
\text { Pegashion }\end{array}$ & The Skiver & $\begin{array}{l}\text { Michael } \\
\text { Monroe }\end{array}$ & Spiral Pegasus \\
\hline $\begin{array}{c}\text { ダーク・ネクロバ } \\
\text { ット }\end{array}$ & Dāku Nekurobatto & Dark Dizzy & Dizzy Reed & Dark Necrobat \\
\hline
\end{tabular}

The case of personage referencing as shown from the boss character names in Rockman X5 indicates the presence of playfulness on real person-to-animated character referencing. In the perspectives of localization, the core value of video game translation, this type of personage referencing generates a question of whether adopting the names of real personages can be considered as a form of localization or not. This question emerges from the fact that references are allusively exercised and that the source texts are in katakana, which is constructed to deliver foreign language expressions via Japanese characters. A different case is found from Agate Studio's Bumbu Cinta, which was translated into Love Spice. The case is as follow:

ST: $\quad$ Lebih ganteng daripada Rio Rahardian.

BT: $\quad$ More handsome than Rio Rahardian.

TT: He's more gorgeous than Chris Hemslock.

Rio Rahardian might refer to Reza Rahardian, a famous Indonesian actor, and Chris Hemslock to the actor of Thor, Chris Hemsworth. This case indicates person-to- 
person reference in which allusions are applied to avoid a direct reference. Its allusive reference leaves the gamers with two questions: whether the two names indeed refer to the assumed names and a question about their degree of equivalence. These two questions further imply that allusive referencing might work both as expressive and explanative functions. In the case of Rio Rahardian-to-Chris Hemslock, expressive function is perceptible from the use of real-life actor as the reference while the explanative function from a presupposition that Rio Rahardian might share similar characters as Chris Hemslock. The latter function evokes a localization problem on how equivalent the localization of Rio Rahardian to Chris Hemslock is. It is the issue that we will address on the third ludification's sub strategy, para-localization.

\subsubsection{Expression Referencing}

Expression referencing is implemented by considering that the source text might prevent target text readers from comprehending the text without any hindrances. Thus, a reference that addresses and adheres to the target culture is deemed necessary. The following example from Sui Arts' Dentures and Demons might help illustrate what expression referencing is:

ST: $\quad$ I'll deal with it later.

TT: Nanti sajalah. Mager.

BT: Later. I don't wanna do anything right now.

The line was expressed by a janitor who was asked to do his job, but he said he would do it later. This refusal to postpone a job leaves a more robust sense in the bahasa Indonesia version since the translator decides to add the expression mager, abbreviated from malas gerak (lit. do not want to do anything even moving one's body an inch). The addition of mager makes the scene sound more local and indicates that the translator fathoms the target users of the game - Indonesian teenagers.

The merriness of mager is seen from the desynchronicity between the sayer and the said expression. The sayer is an old man while the expression is identical to that of a teenager. This desynchronicity between the sayer and the said generates a parodic nuance. The merriness of mager is also perceived from the discrepancy or desynchronicity of the word with its commonly associated activity. Mager is commonly used to refer to footloose activities on couch - watching films while stretching one's body and snacking - but this associated activity is not seen on the scene. The janitor says his line while standing still and gazing something in the skies.

Expression desynchronicity as the reason behind the emergence of merriness covers an unrelated connection between the sayers with the said, the sayers with the sayers' context, the sayers with the contextual scene where the said occurs, and the sayers with the said context. The effect of merriness might occur due to an intentional translation decision or an unintentional one.

ST: Oh boy. Either the sky just got its first case of acne, or something bad is happening...

TT: Amboi. Mungkin langit baru saja berjerawat atau ada hal buruk yang terjadi...

BT: $\quad$ Oh boy. Maybe the sky just got its acne or something bad is happening...

Amboi, as seen from the translation of Gameloft's Spider Man: Unlimited, tends to be feminine in use - implying that a man saying the expression will have, to some 


\section{SF. Luthfie Arguby Purnomo, SF. Lukfianka Sanjaya Purnama, Lilik Untari, Arynaa}

Azahra, Nadya Octaviana Pramana Putri: Proposing a Typology of Ludification as a Translation Technique for PC, Console, Mobile and Online Games

extent, a feminine quality. Spider Man, the sayer of the line, might fit to amboi due to his playful attitudes and love of making characters through voices and gestures. The decision to translate oh boy into amboi indicates ludification in the desynchronicity between what amboi is identical to, the sayer, and a word play of boy and amboi which leaves rhymical sound. This desynchronicity might be unintentional since amboi contextually fits with oh boy, which signifies surprises and astonishment. Textually no rule breaking is spotted from the translation of oh boy but culturally it might indicate a rule breaking.

\subsubsection{Para-Localization}

When localization is applied, it implies that the translated textual item has a certain degree of equivalence as the source textual item. This condition further implies that the translated item is culturally existent in the target text. However, this is not always the case since the implementation of localization might indicate the absence of equivalence and of existence. This absence drives the presence of playful nuance.

For instance, in Nexon's Darkness Rises, Berserker is localized into Pengamuk (lit. the one who goes berserk). Berserker, Warrior, Wizard, Witch, Assassin, Archer, and Guardian are so-called jobs or character classes - a formulaic feature in Role Playing Games, especially Massively Multiplayer Online Role Playing Games (MMORPG). Players have to select one of the jobs befitting to their playing type. Each job has a unique feature differentiating itself from the other jobs and this job corresponds to the playing type of the players. These jobs take the references from epic lore or real troop divisions. Berserker, for example, is a part of Viking's frontliners commonly depicted as death seeking fearless double-handed sword wielder. Pengamuk fails to cover this cultural reference and, to some extent, unintentionally evokes a playful nuance since pengamuk is existent in Indonesian dictionary but it is nonexistent in Indonesian cultural domain. This nuance is further strengthened by the fact that Wizard and Witch are localized into the same word, penyihir. It might generate confusion for the players since two different jobs have the same name. It occurs since the translator attempts to preserve consistency in localizing all of the job names.

Para-localization deals with the nonexistence of reference in the target culture and refers to the nonexistence of semantic synchronicity between the source and the target texts. In Square Enix's Final Fantasy XIII, for instance, the main protagonist, Lightning, has to collect magical dresses called garbs to ready the protagonist for fights against various monsters. These garbs have various names, functions, and abilities. The names of the garbs are aesthetically aligned with the functions and abilities in allusive and direct manners. Dragon's Blood, for example, has a direct reference to the winged costume and an allusive reference on the blood part seen from the blood-like color of the garb. The problem occurs when translation is applied. There might be possibilities that the source garb name might end up in a desynchronicity with the target garb name after the garb is translated. School's Out, which is the translation of セイントダムゼル (seintodamuzeru), shares a visual synchronicity with the high school uniform like garb that Lightning wears. The translator preferred translating セイントダムゼル into School's Out to Saint Damsel, which should have been the literal translation of セイン トダムゼル to match the visual of high school uniform. The problem is that an adult wears the uniform and this context generates a contextual merriness. 


\subsection{Discussion}

Translation, which is carried out by breaking translation rules or standards, might and might not generate merriness. Merriness is made possible due to what Mangiron \& O'Hagan (2013) call the translators' carte blanche. Purnomo et al. (2016) call video game translation a ludic translation since it has specific what-to-do, how-todo, and why-to-do, from which playfulness might arise. These specific to-dos disclose possibilities for rule-breaking and contextual merriness, from which ludification roots. The problem with this specific term of video game translation is how ludic a translation should undergo to become a 'ludic translation'. To address this issue, ones have to adhere to the concept of ludicity.

Ludicity, as Lopes (2005) suggests and Liang (2012) implies a condition, a manifestation, and an effect circumnavigating around play, game playing, recreation, leisure, and creative object construction. The presence of ludicity within games and gaming signifies their ludic nature and further implying that any activities related to them are a part of their ludicity. Therefore, to reveal whether both the games and game translations might share the same level of ludicity is necessary for the context of what Fernández Costales (2012) calls as enjoying the same gameplay experiences between source gamers and target gamers. That translated games should be on the same level of ludicity as the source games require an assessment model, which might work as a quality assessment.

To implement ludicity as a means to spot how ludic a translation can be, ones have to address the issue of ludicity types. Conway (2010) classifies ludicity into contra and hyper-ludicity. The former pits the games against the gamers with the games having more forces to dictate the gamers. On the other hand, the latter has contextual forces which bridge how the games dictate the gamers and how the gamers react and respond to that dictative force. Conway illustrates contra-ludicity with Tetris games where the blocks are getting faster each time the gamers advance to the next stages or levels - all the gamers could do is react and respond faster. Meanwhile, hyper-ludicity could be found in RPG titles, which mostly provide 'solutions' for gamers when they are stuck with the games. This condition implies that when the gamers are unable to defeat a certain boss, they can always grind their levels to match the boss's level.

Implementing ludicity types to assess how ludic a translation is points out that the concept of being 'contra' and 'hyper' needs to be addressed and recontextualized to serve the purpose of the assessment. Contra-ludicity concept might be applied on ludicity assessment regarding rule breaking on narrative, mechanics, or both indicates a different level of ludicity. Rule breaking only on the narrative or mechanic aspects rationally indicates a lower degree of ludicity than rule breaking occurring on both aspects. Meanwhile, hyper-ludicity concept might be applied regarding the synchronicity between the comedic or playful nuance of the game. The translation - a game title designed to incite a playful nuance should be translated under the umbrella of playfulness and vice versa. Thus, if the playfulness of games like Buff Knight can be maintained in the translation version, it implies that the ludicity level is on the same level as the source game. The problem is that the same ludicity level might not work properly in localization perspectives - target culture, market, and audiences might find that the same level of ludicity as the source game is unfit with them. Thus, a consideration over localization needs to be addressed when proposing an assessment. 


\section{SF. Luthfie Arguby Purnomo, SF. Lukfianka Sanjaya Purnama, Lilik Untari, Arynaa}

Azahra, Nadya Octaviana Pramana Putri: Proposing a Typology of Ludification as a Translation Technique for PC, Console, Mobile and Online Games

Considering localization over ludic level assessment indicates that ludic level shifts might occur due to adherence to the target culture. This condition implies that these shifts are not always an indicator that the translation quality is poor. Since game translation, as implied by Pyae (2018), not only circumnavigates around textual, audio, visual, and digital elements but also the elements of the target culture, localization and culturalization are the issues game translators need to address. Localization might guarantee acceptability level but a significant problem on compromising between the game identity and the target culture identity remains problematic. This problem generates a peculiar complexity in assessing whether a particular localization has met what the target culture demands or not. In the perspectives of ludicity, ludicity might occur due to considerations over the target culture. Rockman X5's case on Guns n Roses' name adaptation is the example. The rule-breaking, as shown from the boss character naming disrupts the game's identity, which causes the shift on what Petrucci (2012) addresses as character equivalence, where source identity might shift when translated.

\section{Conclusion}

We argue that ludification can be included as a translation technique since it has specific characteristics and functions in translation context. The characteristics of ludification are the presence of rule-breaking to evoke contextual merriness in the target texts. These characteristics are not found in the other translation techniques. This contextual merriness is aimed at providing explanative and expressive functions. Each of the functions is delivered through the subtypes of ludification namely emojization, referencing, and para-localization. Emojization deals with adding emoji on the target texts, referencing with taking objects, personages, and expressions as references from the target culture to fit the target text, and para-localization with localizing any information which has no actual existence in the target culture. Through ludification techniques, translation scholars or practitioners could comprehend how translation might deliver its light through playfulness.

\section{References}

Baños, R. (2020). Fandubbing. In The Palgrave Handbook of Audiovisual Translation and Media Accessibility (pp. 209-226).

Chaume, F. (2004). Film Studies and Translation Studies: Two Disciplines at Stake in Audiovisual Translation. Meta, 49(1), 12-24. https://doi.org/10.7202/009016ar

Consalvo, M. (2013). Unintended Travel: ROM Hackers and Fan Translations of Japanese Video Games. In Gaming Globally Production, Play, and Place (pp. 119138). Palgrave Macmillan US.

Conway, S. (2010). Hyper-ludicity, contra-ludicity, and the digital game. Eludamos. Journal for Computer Game Culture, 4(2), 135-147.

Cronin, M. (1995). Altered States: Translation and Minority Languages. TTR: Traduction, Terminologie, Rédaction, 8(1), 85-103. https://doi.org/10.7202/037198ar

Cronin, M. (2007). Keeping One's Distance: Translation and the Play of Possibility. TTR: Traduction, Terminologie, Rédaction, 8(2), 227-243. https://doi.org/10.7202/037225ar

Ding, N., Yang, Z., Li, S., \& Zhang, A. (2021). Where translation impacts: The nonprofessional community on Chinese online social media - A descriptive case 
study on the user-generated translation activity of Bilibili content creators. Global Media and China, 205943642110006. https:/ / doi.org/10.1177/20594364211000645

Đorđević, J. (2017). Translation techniques revisited: The applicability of existing solutions in non-literary translation. FACTA UNIVERSITATIS-Linguistics and Literature, 15(1), 35-47.

Fawcett, P. (2003). The manipulation of language and culture in film translation. In Apropos of ideology: Translation studies on ideology-ideologies in translation studies (pp. 145-163).

Fernández Costales, A. (2012). Exploring translation strategies in video game localization. MonTI. Monografías de Traducción e Interpretación, 4, 385-408. https:/ / doi.org/10.6035/MonTI.2012.4.16

Frissen, V. (Ed.). (2015). Playful identities: The ludification of digital media cultures. Amsterdam University Press.

Gambier, Y. (2010). Translation strategies and tactics. In Handbook of Translation Studies (Vol. 1, pp. 412-417). John Benjamins Publishing Company.

Guyker Jr., R. W. (2016). Myth in translation: The ludic imagination in contemporary video games [Dissertation]. Pacifica Graduate Institute.

Huizinga, J. (2014). Homo ludens: A study of the play-element in culture.

Inose, H. (2012, June 10). Scanlation-What Fan Translators of Manga Learn in the Informal Learning Environment. The Proceedings Book of ISLC 2012, 201. International Symposium on Language and Communication: Research Trends and Challenges, IICS (Institute of Language and Communication Studies), Izmir University.

Korhonen, H., Montola, M., \& Arrasvuori, J. (2009, October). Understanding playful user experience through digital games. International Conference on Designing Pleasurable Products and Interfaces. International Conference on Designing Pleasurable Products and Interfaces, Compiegne University of Technology.

Krings, H. P. (1986). Translation Problems and Translation Strategies of Advanced. In Interlingual and intercultural communication: Discourse and cognition in translation and second language acquisition studie (pp. 263-272). Gunter Narr Verlag.

Liang, M.-Y. (2012). Foreign ludicity in online role-playing games. Computer Assisted Language Learning, 25(5), 455-473. https:/ / doi.org/10.1080/09588221.2011.619988

Lopes, C. (2005). Ludicity - a theoretical term. Sixth Annual Convention of Media Ecology Association, 1-10.

Mangiron, C., \& O’Hagan, M. (2006). Game Localisation: Unleashing imagination with 'restricted'translation. JoSTrans: The Journal of Specialised Translation, 6(1).

Massidda, S. (2015). Audiovisual Translation in the Digital Age. Palgrave Macmillan. http://www.myilibrary.com?id=690618

Molina, L., \& Hurtado Albir, A. (2004). Translation Techniques Revisited: A Dynamic and Functionalist Approach. Meta, 47(4), 498-512. https://doi.org/10.7202/008033ar

Nord, C. (2003). Proper Names in Translations for Children: Alice in Wonderland as a Case in Point. Meta, 48(1-2), 182-196. https:/ / doi.org/10.7202/006966ar

Nord, C. (2018). Translating as a purposeful activity: Functionalist approaches explained. http://search.ebscohost.com/login.aspx?direct=true\&scope=site\&db=nlebk\&db $=$ nlabk\&AN=1714814 
SF. Luthfie Arguby Purnomo, SF. Lukfianka Sanjaya Purnama, Lilik Untari, Arynaa Azahra, Nadya Octaviana Pramana Putri: Proposing a Typology of Ludification as a

Translation Technique for PC, Console, Mobile and Online Games

Petrucci, P. (2012). The translation of cinematic discourse and the question of character equivalence in Talk to me. Multilingua, 31(2-3). https://doi.org/10.1515/multi2012-0011

Purnomo, SF. L. A., Nababan, M. R., Riyadi, S., \& Kristina, D. (2016). Game time: Revisiting ludic linguistics for video game analysis. Prasasti, 689-694.

Purnomo, SF. L. A., Untari, L., Purnama, SF. L. S., Asiyah, N., Umam, R. K., Sartika, Y., Anggraini, N., \& Inderasari, E. (2021). Ludic Adaptation: Can We Babyfy, Chibify, Bambify, or Cherubify a Literary Text for Younger Audiences? GEMA Online ${ }^{\circ}$ Journal of Language Studies, 21(1), 89-109. https://doi.org/10.17576/gema-2021-2101-06

Pyae, A. (2018). Understanding the role of culture and cultural attributes in digital game localization. Entertainment Computing, 26, 105-116. https://doi.org/10.1016/j.entcom.2018.02.004

Reiss, K., \& Vermeer, H. J. (2014). Towards a General Theory of Translational Action: Skopos Theory Explained. Taylor and Francis.

Schules, D. M. (2012). Anime fansubs: Translation and media engagement as ludic practice [Doctor of Philosophy, University of Iowa]. https://doi.org/10.17077/etd.asy4on82

Spradley, J. P. (2016). Participant observation. Waveland Press. 